University of Nebraska - Lincoln

DigitalCommons@University of Nebraska - Lincoln

2006

Poststocking Movements and Habitat Use of Hatchery-Reared Juvenile Pallid Sturgeon in the Missouri River below Fort Randall Dam, South Dakota and Nebraska

\author{
George R. Jordan \\ U.S. Fish and Wildlife Service \\ Robert A. Klumb \\ Greg A. Wanner \\ Wayne J. Stancill
}

Follow this and additional works at: https://digitalcommons.unl.edu/usfwspubs

Part of the Aquaculture and Fisheries Commons

Jordan, George R.; Klumb, Robert A.; Wanner, Greg A.; and Stancill, Wayne J., "Poststocking Movements and Habitat Use of Hatchery-Reared Juvenile Pallid Sturgeon in the Missouri River below Fort Randall Dam, South Dakota and Nebraska" (2006). US Fish \& Wildlife Publications. 82.

https://digitalcommons.unl.edu/usfwspubs/82

This Article is brought to you for free and open access by the US Fish \& Wildlife Service at DigitalCommons@University of Nebraska - Lincoln. It has been accepted for inclusion in US Fish \& Wildlife Publications by an authorized administrator of DigitalCommons@University of Nebraska - Lincoln. 


\title{
Poststocking Movements and Habitat Use of Hatchery-Reared Juvenile Pallid Sturgeon in the Missouri River below Fort Randall Dam, South Dakota and Nebraska
}

\author{
George R. Jordan, ${ }^{*}{ }^{1}$ Robert A. Klumb, Greg A. Wanner, and Wayne J. Stancill \\ U.S. Fish and Wildlife Service, 420 South Garfield Avenue, Suite 400, Pierre, South Dakota 57501, USA
}

\begin{abstract}
Telemetry was used to evaluate seasonal and diel movement patterns, general habitat use, survival, and spatial distributions of hatchery-reared juvenile pallid sturgeon Scaphirhynchus albus stocked in the Missouri River below Fort Randall Dam, South Dakota and Nebraska. Sampling occurred at about 2-week intervals during spring through fall. Of 22 ultrasonically tagged fish, 13 were intensively followed to assess hourly diel movement rates. A total of 258 relocations were made for the 22 tagged fish; 19 fish were relocated at least once, and 16 were relocated multiple times. At least $68 \%$ of tagged fish survived for 2.5 years. In 2000, fish were found mainly upstream of the stocking site, whereas in 2001 and 2002 the entire reach was used. Juveniles were found primarily in the main channel at depths exceeding $80 \%$ of the maximum channel cross-section depth, where bottom current velocities ranged from 0.1 to $0.9 \mathrm{~m} / \mathrm{s}$. Clusters of juvenile pallid sturgeon (i.e., two or more fish) within $750 \mathrm{~m}$ of each other were observed on 15 dates, and clusters of juveniles within $500 \mathrm{~m}$ of each other were observed on 10 dates. Clusters were observed during all seasons. Mean ( \pm 2 SE) range of movement was significantly less in $2000(8.3 \pm 5.8 \mathrm{~km})$ than in $2001(29.3 \pm 8.8$ $\mathrm{km})$ and $2002(28.9 \pm 15.0 \mathrm{~km})$. We detected no significant differences in movement rates among years, seasons, or diel periods (i.e., dawn, daytime, dusk, and night). Our study indicates that range of movements of juvenile pallid sturgeon based on shorter studies (i.e., $\leq 1$ year) should be interpreted cautiously because hatchery-reared fish may not have acclimated to the riverine environment until the second year after stocking. Based on survival and distribution of juvenile pallid sturgeon throughout the study area, we conclude that this reach is suitable for recovery efforts.
\end{abstract}

Pallid sturgeon Scaphirhynchus albus, a species native to the Missouri River system (Forbes and Richardson 1905), are long lived and exhibit delayed sexual maturation. Males reach sexual maturity at around 533-584 mm total length (Fogle 1961), which corresponds with ages 5-7 in the wild; females mature later, usually at around $850 \mathrm{~mm}$ fork length (FL) at ages 13-15 (Keenlyne and Jenkins 1993). Pallid sturgeon were listed as an endangered species (U.S. Endangered Species Act) in the fall of 1990 (Dryer and Sandvol 1993). Conversion of the free-flowing upper Missouri River into a series of impoundments and extensive channelization of the lower Missouri River have resulted in habitat degradation and an altered discharge pattern suspected to be responsible for declines in distribution and abundance of pallid sturgeon (Kallemeyn 1983; Pegg et al. 2003). In the lower Mississippi River, pallid sturgeon are benthic and tend to be found in main-channel habitats (Hurley et al. 2004). In the upper Missouri River, wild pallid

\footnotetext{
* Corresponding author: george_jordan@fws.gov

${ }^{1}$ Present address: U.S. Fish and Wildlife Service, 2900 Fourth Avenue North, Suite 301, Billings, Montana 59101, USA.

Received August 4, 2005; accepted May 25, 2006 Published online November 9, 2006
}

sturgeon adults were found in main-channel areas associated with islands or sand bars (Bramblett and White 2001).

Population supplementation with hatchery-reared pallid sturgeon is one facet of recovery efforts for pallid sturgeon in the Missouri River (Dryer and Sandvol 1993). An unchannelized reach of the Missouri River below Fort Randall Dam was identified as a recovery priority management area (RPMA) by the Pallid Sturgeon Recovery Team (Dryer and Sandvol 1993). This section of the Missouri River, designated as RPMA 3, was chosen for stocking of hatcherypropagated pallid sturgeon because it retains many natural riverine features. In 2000, the first stocking of 416 age-3 hatchery-reared juvenile pallid sturgeon occurred in RPMA 3.

Biotelemetry studies are a common and useful tool to develop understanding of fish movements and habitat use (Nielsen 1992; Winter 1996). This study is the first telemetry work with hatchery-reared juvenile pallid sturgeon to occur downstream of Fort Randall Dam in RPMA 3. Past telemetry studies with pallid sturgeon focused primarily on wild adults in the Mississippi (Hurley et al. 2004) and Missouri rivers (Erickson 1992; Bramblett and White 2001). Only one telemetry study has been completed using hatcheryreared juveniles in the Missouri River, but it was 
conducted above Fort Peck Dam, Montana (Gerrity 2005). Telemetry has been used to assess habitat use and movements of both hatchery-reared juvenile pallid sturgeon and wild-caught pallid sturgeon in the Platte River, a major Missouri River tributary in Nebraska (Snook et al. 2002; Swigle 2003). However, Gerrity (2005) and both studies in the Platte River used shortduration transmitters $(\leq 400 \mathrm{~d})$. Our study is the first to assess long-term (transmitter life $>1,095 \mathrm{~d}$ ) movement and distribution patterns of hatchery-reared juvenile pallid sturgeon stocked into the Missouri River.

The progress and ultimate success of any endangered species recovery effort involving population supplementation requires assessment of how captive-bred animals transition to the natural environment. Of the 416 hatchery-reared pallid sturgeon juveniles released in the Missouri River downstream of Fort Randall Dam during 2000, 22 were implanted with sonic transmitters. Using transmitters with a battery life greater than 1 year enabled study of the transition of these fish to the riverine environment beyond immediate poststocking movements. Objectives of this study were to document seasonal and diel movement patterns, general habitat use, survival, and spatial distribution of hatchery-reared juvenile pallid sturgeon after stocking. Assessing initial stocking success, evaluating stocking site location, and assessing initial movements and habitat associations of hatchery-reared pallid sturgeon within this reach are required to determine whether this flow-regulated, unchannelized reach (RPMA 3) of the Missouri River is suitable for reestablishing a pallid sturgeon population.

\section{Study Area}

Gavins Point Dam on the Missouri River was closed in 1955 and formed Lewis and Clark Lake (Figure 1). This reservoir forms a boundary between the states of South Dakota and Nebraska and can be subdivided into two distinct habitats: riverine and reservoir. The upper reach extends for approximately $85 \mathrm{~km}$ from Fort Randall Dam (river kilometer [rkm] 1,416) to downstream of Springfield, South Dakota (rkm 1,340), and still retains many natural riverine characteristics, including sand bars, old-growth riparian forest, side channels, and one large, unregulated tributary (Niobrara River). Because of these remaining riverine characteristics, this upper reach was chosen for stocking of pallid sturgeon as part of the recovery plan (Dryer and Sandvol 1993). However, discharge is regulated by Fort Randall Dam. River stage fluctuates daily $(>0.75 \mathrm{~m})$, and mean daily discharge in May through October ranged from 400 to $1,000 \mathrm{~m}^{3} / \mathrm{s}$ during 2000-2002 (Figure 2). Discharge patterns were similar during 2000-2002, except that discharge in spring 2001 was lower than in the other years because of regulation for flood control. The second habitat, which extends downstream of Springfield, South Dakota, to Gavins Point Dam, is composed of the reservoir, Lewis and Clark Lake.

\section{Methods}

Pallid sturgeon for this telemetry project were progeny from wild broodstock collected near the confluence of the Missouri and Yellowstone rivers in North Dakota, spawned in 1997, and reared for 3 years at Gavins Point Dam National Fish Hatchery (NFH) in Yankton, South Dakota. Fifty age-3 fish (520-613 mm FL, 700-1,150 g) were surgically implanted with sonic transmitters (Sonotronics, Tuscon, Arizona) using techniques similar to those described in Nielsen (1992). Transmitters were $60 \mathrm{~mm}$ in length and 18 $\mathrm{mm}$ in diameter. Transmitter weights were approximately $25 \mathrm{~g}$ and transmitter weight : fish body weight ratios ranged from $2.1 \%$ to $3.5 \%$. Each transmitter emitted a unique aural code that identified individual fish and had a life expectancy (battery life) of 36 months. Frequencies ranged from 69 to $79 \mathrm{kHz}$. Hatchery water temperatures at the time of tagging in late July were $19-20^{\circ} \mathrm{C}$. No anesthesia was used during surgery, and implanted fish were held at the hatchery for 2 weeks after surgery to assess tag expulsion and mortality. After this holding period, surviving fish were released in the Missouri River near Verdel, Nebraska (rkm 1,377), on August 2, 2000 (Table 1).

Before stocking, transmitter detection range was evaluated in the Missouri River by placing a test transmitter in a plastic bottle partially filled with water. The bottle was affixed at various locations and depths to estimate maximum distance of detection. Given the variety of background noise inherent with sonic transmitter detection in lotic environments and to ensure the highest probability of detection, we determined that the greatest rates of detection were at distances of approximately $0.5 \mathrm{~km}$. To maximize detection rates, our sampling efforts did not exceed $0.4 \mathrm{~km}$ between detection attempts and shorter distances were used in areas with islands and sandbars.

The riverine reach was divided into four sample zones of approximately equal length (Figure 1). The upper site extended from Fort Randall Dam (rkm 1,416) to downstream of Greenwood, South Dakota (rkm 1,392). The upper-middle site extended from Greenwood to near Verdel, Nebraska (rkm 1,377), and the lower-middle site extended from Verdel to Running Water, South Dakota (rkm 1,360). The most downriver site encompassed the remainder of the river from Running Water to near Springfield, South Dakota (rkm 1,340). Surveys of all four zones were conducted on four dates in 2000, 13 dates in 2001, and 10 dates in 

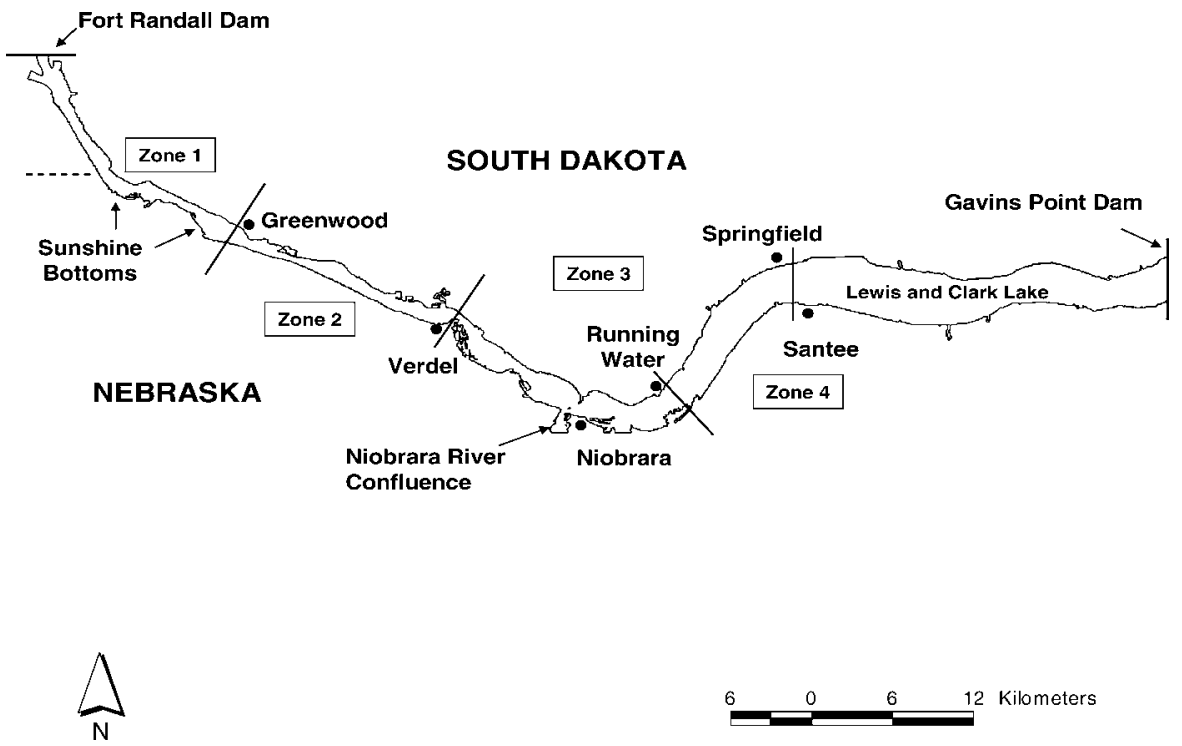

FIGURE 1.-Map showing the Missouri River in South Dakota and Nebraska, where sonically tagged, hatchery-reared juvenile pallid sturgeon were released on August 2, 2000, near Verdel, Nebraska, and tracked during 2000-2002. The Missouri River was divided into four zones to facilitate tracking effort.

2002. One survey date in 2002 occurred during winter (January). Lewis and Clark Lake was also searched once in 2000 and once in 2001. To locate fish near the end of the expected battery life of the transmitters, ad hoc sampling was conducted on two occasions in 2003 in areas that had been commonly occupied by juvenile pallid sturgeon during 2000-2002.
Two tracking methods, extensive and intensive, were employed during each sample period. Extensive tracking ascertained the locations of as many fish as possible in each zone by stopping and listening for fish about every $0.4 \mathrm{~km}$. After extensive tracking, one of the four sampling zones was randomly selected and an individual fish was then randomly selected from all the

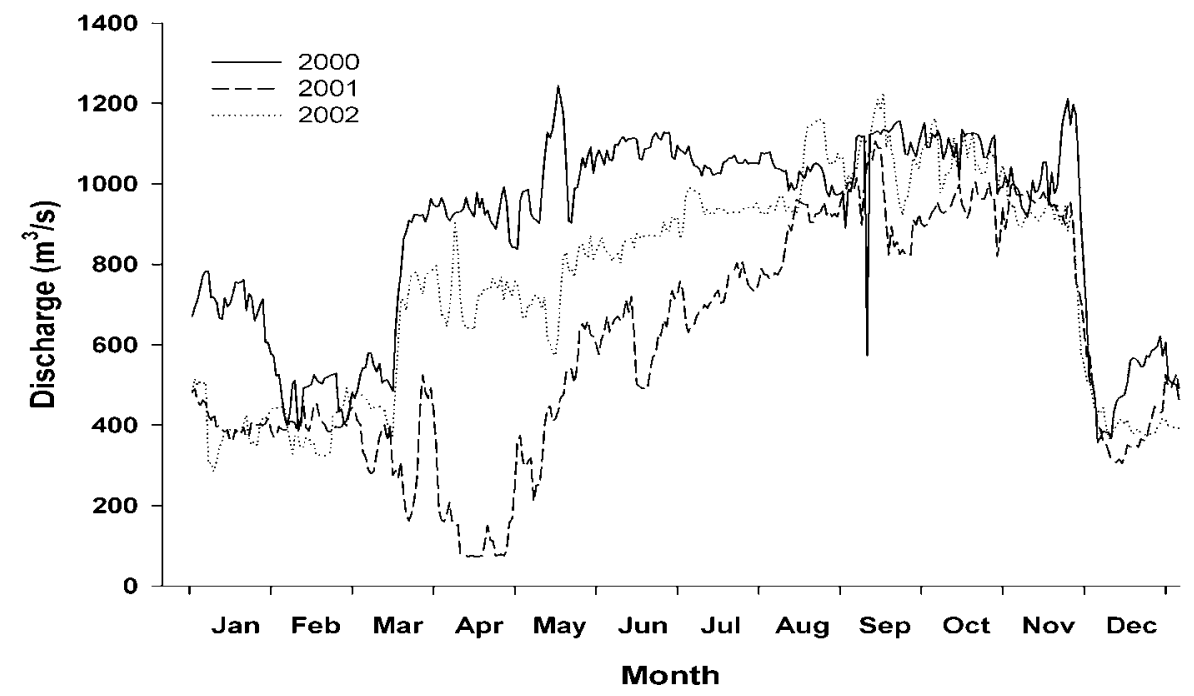

FIGURE 2.- Missouri River mean discharge from Fort Randall Dam, South Dakota, during 2000-2002. Discharge data were provided by the U.S. Army Corps of Engineers, Northwest Division, Missouri River Basin Water Management Division, Omaha, Nebraska. 
TABLE 1.- Size at tagging, relative condition $\left(K_{n}\right)$ at tagging, number of relocations, and days at large for juvenile hatcheryreared pallid sturgeon $(N=22)$ implanted with ultrasonic transmitters and stocked in the Missouri River below Fort Randall Dam near Verdel, Nebraska, on August 2, 2000. Relative condition was calculated using the length-weight regression in Keenlyne and Evenson (1993).

\begin{tabular}{|c|c|c|c|c|c|c|c|c|c|c|}
\hline \multirow[b]{2}{*}{$\begin{array}{c}\text { Transmitter } \\
\text { number }^{\mathrm{a}}\end{array}$} & \multirow[b]{2}{*}{$\begin{array}{l}\text { Fork length } \\
\quad(\mathrm{mm})\end{array}$} & \multirow[b]{2}{*}{ Weight (g) } & \multirow[b]{2}{*}{$K_{n}$} & \multirow[b]{2}{*}{ Date last located } & \multirow[b]{2}{*}{ Days at large } & \multirow[b]{2}{*}{$\begin{array}{c}\text { Total } \\
\text { relocations }\end{array}$} & \multicolumn{4}{|c|}{ Relocations in year: } \\
\hline & & & & & & & 2000 & 2001 & 2002 & $2003^{\mathrm{b}}$ \\
\hline 25 & 570 & 900 & 1.20 & Sep 24, 2002 & 780 & 20 & 3 & 9 & 8 & \\
\hline 46 & 581 & 850 & 1.07 & Mar 31, 2003 & 971 & 15 & 2 & 8 & 4 & 1 \\
\hline 57 & 562 & 800 & 1.12 & Mar 31, 2003 & 971 & 12 & 2 & 5 & 4 & 1 \\
\hline 66 & 560 & 800 & 1.14 & Aug 6, 2002 & 734 & 8 & & 5 & 3 & \\
\hline 77 & 555 & 850 & 1.24 & May 7, 2002 & 643 & 9 & 1 & 6 & 2 & \\
\hline 79 & 605 & 900 & 0.99 & Jul 9, 2002 & 706 & 7 & & 5 & 2 & \\
\hline 267 & 546 & 814 & 1.26 & Aug 14, 2000 & 12 & 1 & 1 & & & \\
\hline 275 & 584 & 850 & 1.05 & Oct 23,2002 & 812 & 17 & 2 & 7 & 8 & \\
\hline 336 & 585 & 1,000 & 1.23 & Oct 16,2001 & 440 & 3 & & 3 & & \\
\hline 356 & 585 & 900 & 1.10 & Oct 21,2002 & 810 & 18 & 1 & 9 & 8 & \\
\hline 366 & 572 & 1,100 & 1.45 & Oct 21,2002 & 810 & 15 & 2 & 7 & 6 & \\
\hline 399 & 559 & 800 & 1.14 & Aug 17, 2000 & 15 & 1 & 1 & & & \\
\hline 455 & 592 & 950 & 1.12 & Aug 14, 2000 & 12 & 1 & 1 & & & \\
\hline 468 & 586 & 900 & 1.10 & Oct 21,2002 & 810 & 19 & 3 & 8 & 8 & \\
\hline 2345 & 562 & 700 & 0.98 & Oct 21,2002 & 810 & 15 & 2 & 8 & 5 & \\
\hline 2633 & 565 & 900 & 1.24 & Apr 1, 2003 & 972 & 22 & 1 & 10 & 10 & 1 \\
\hline 3344 & 585 & 850 & 1.04 & Jul 31, 2003 & 1,093 & 18 & 2 & 8 & 7 & 1 \\
\hline 3568 & 580 & 850 & 1.07 & Sep 24,2002 & 783 & 14 & 1 & 7 & 6 & \\
\hline 213313 & 575 & 1,000 & 1.30 & Apr 2, 2003 & 973 & 17 & 1 & 6 & 9 & 1 \\
\hline
\end{tabular}

a Three fish were never relocated.

b Relocations in 2003 were the result of ad hoc sampling conducted near the end of battery life for the transmitters.

fish found in that zone. This randomly selected individual was relocated hourly during each diel tracking period; most fish were monitored for at least two periods (Table 2). Diel tracking periods were defined as dawn ( $1 \mathrm{~h}$ before to $1 \mathrm{~h}$ after sunrise), day (2 $\mathrm{h}$ after sunrise to $2 \mathrm{~h}$ before sunset), dusk ( $1 \mathrm{~h}$ before to $1 \mathrm{~h}$ after sunset), and night ( $2 \mathrm{~h}$ after sunset to $2 \mathrm{~h}$ before sunrise). Tracking began immediately after stocking, and sample periods were conducted at approximately 2-3-week intervals thereafter until weather conditions prohibited tracking during late fall; tracking resumed as early as was feasible in the subsequent spring.

An ultrasonic receiver and directional hydrophone were used to detect fish. Fish were considered located

TABLE 2.- Total number of surveys and number of hourly observations in each diel period for intensively tracked hatchery-reared juvenile pallid sturgeon relocated during 2000-2003 after stocking in the Missouri River downstream of Fort Randall Dam near Verdel, Nebraska, on August 2, 2000. Number in parentheses represents the total number of unique tracked fish.

\begin{tabular}{rrrrrr}
\hline & & \multicolumn{4}{c}{ Diel period } \\
\cline { 3 - 6 } Year & $N$ & Dawn & \multicolumn{1}{c}{ Day } & \multicolumn{1}{c}{ Dusk } & Night \\
\hline 2000 & 4 & $3(1)$ & $6(1)$ & $9(3)$ & $6(1)$ \\
2001 & 11 & $24(7)$ & $71(7)$ & $24(7)$ & $28(6)$ \\
2002 & 7 & $18(6)$ & $43(5)$ & $15(4)$ & $11(3)$ \\
\hline
\end{tabular}

when the coded impulses from the sonic transmitter were equally audible with a $360^{\circ}$ rotation of the hydrophone. Once a fish location was determined, latitude and longitude coordinates were recorded with a PLGR + 96 global positioning system (GPS) receiver (Rockwell International, Milwaukee, Wisconsin). The mean error reading measured by the PLGR $+96(N=$ $529)$ for GPS coordinates was $5.5(2 \mathrm{SE}=0.2) \mathrm{m}$. The habitat type for each located fish was classified as main channel, side channel, backwater, island tip, reservoir, tributary mouth, or dam tailrace. Habitat characteristics measured at each fish location included surface water temperature $\left({ }^{\circ} \mathrm{C}\right)$, maximum water depth $(\mathrm{m})$ of the channel cross section, water depth (m), bottom current velocity $(\mathrm{m} / \mathrm{s})$, and turbidity (nephelometric turbidity units [NTU]). The relative depth for each location was calculated as the ratio of the water depth at the fish's location to the maximum water depth of the channel cross section.

Data analysis.-To evaluate postsurgery survival, a $t$ test was used to compare mean weights, lengths, relative condition factor $\left(K_{n}\right)$, and transmitter weight : fish weight ratios for pallid sturgeon that survived the transmitter implantation process with those of fish that died within 2 weeks postsurgery. Relative condition was calculated using the relation in Keenlyne and Evenson (1993). All fish were held at about $20^{\circ} \mathrm{C}$ in the same tank under a natural photoperiod at Gavins Point Dam NFH.

Movements of juvenile pallid sturgeon were com- 
pared among the 3 years of study (2000-2002), three seasons (spring, summer, and fall), and four diel periods (dawn, day, dusk, and night). Seasons were delineated by the dates of the spring and fall equinoxes and summer and winter solstices. Winter data were excluded from all analyses because only a single extensive survey was made in that season. Multiple relocations of individual fish can inflate the sample size in statistical analyses. However, we considered data for fish relocated during extensive surveys on separate dates to be independent (Bramblett and White 2001), and autocorrelation between locations was minimized by using a tracking interval greater than or equal to 2 weeks (Winter 1996). An individual fish was intensively followed twice during 2001 and 2002, but these surveys occurred in different seasons (spring and summer of both years) and were also considered independent when comparing movement among diel periods. Statistical significance $(\alpha)$ for all analyses was set at 0.10 .

The range of movement and movement rates were visualized with box plots, where the box delineates the interquartile range (i.e., 25th and 75th percentiles) and the horizontal line indicates the median (Hintze 2005). The upper whisker is the largest observation that is less than or equal to the 75 th percentile plus 1.5 times the interquartile range; the lower whisker is the smallest observation that is greater than or equal to the 25th percentile minus 1.5 times the interquartile range. Dots indicate outliers with values exceeding three times the interquartile range.

Extensive surveys were used to determine the ranges and directionality of fish movements, whereas movement rates were calculated only from intensively followed fish. Range of movement was calculated as the linear distance $(\mathrm{km})$ along the river between the fish's most upstream and most downstream locations with a year and season. Directional movement for individual fish relocated multiple times each year during extensive tracking surveys was categorized as upstream or downstream. Directionality of movement determined from fish relocated during extensive surveys among the 3 years and seasons was analyzed separately with chi-square tests. Movement rates $(\mathrm{km} /$ h) of individual fish were calculated by dividing the linear river distance from successive locations by the elapsed time between these locations. Hourly diel movement rates from the same individual fish on a given date were averaged. Distances between locations for each individual fish were measured with the geographical information systems (GIS) software, ArcView version 3.2 (ESRI 1999). To assess spatial separation, distances between different fish on each sampling date were calculated using the statistical program R (Venables et al. 2006).

A repeated-measures analysis of variance (ANOVA) was used to compare the range of movement among the 3 years (2000-2002), the range of movement among the three seasons, and movement rates among the four diel periods. If the factor levels of year, season, or diel period were significant, differences among the levels of these factors were assessed using Tukey-Kramer 90\% family-level confidence intervals. Movement rates did not appear to be normally distributed, based on residual and normal probability plots, so data were $\log _{10}$ transformed. Because we had only 22 total intensive surveys and unequal samples for years and seasons, differences in movement rates of pallid sturgeon were tested separately for year and season using a one-way Kruskal-Wallis test (Sprent and Smeeton 2001). If a model was significant, differences among years or seasons were assessed using Tukey-Kramer $90 \%$ family level confidence intervals.

\section{Results \\ Postsurgery Survival}

There was substantial mortality and shedding of transmitters by juvenile pallid sturgeon during the 2week postsurgery holding period. Of the initial 50 implanted fish, about 50\% had ruptured sutures, exhibited excessive inflammation at the incision site, or had completely shed their tags. During the holding period, 28 fish died $(56 \%)$. There was no difference in weight $(t=-1.13, \mathrm{df}=49, P=0.27)$, FL $(t=-0.86$, df $=49, P=0.40)$, relative condition $(t=-0.58, \mathrm{df}=49$, $P=0.56)$, or transmitter weight : fish weight ratio ( $t=$ $1.26, \mathrm{df}=49, P=0.21$ ) between fish that survived the holding period and fish that died. Twenty-two ultrasonically tagged juvenile pallid sturgeon were subsequently stocked into the Missouri River.

Out of the 22 age- 3 juvenile pallid sturgeon that were stocked in 2000, 19 were relocated at least once during the study and 15 fish were relocated in 2002, suggesting a minimum survival rate of $68 \%$ for the study period. Relocated pallid sturgeon included 3 fish that were located only during the first year after stocking, 4 fish that were not located in the first year after stocking but were found in subsequent years, and 13 fish that were located in all 3 years of the study (Table 1). Of these 13 fish relocated in all 3 years, 8 had multiple relocations in each year. In 2003, $22 \%$ of fish were relocated during ad hoc sampling near the end of the battery life for the transmitters.

\section{Habitat}

In all seasons, over $90 \%$ of juvenile pallid sturgeon were located in the main-channel habitat (Table 3), 
TABLE 3.-Mean seasonal habitat characteristics $( \pm 2 \mathrm{SE})$ where juvenile hatchery-reared pallid sturgeons implanted with ultrasonic transmitters and stocked in the Missouri River below Fort Randall Dam were relocated during 2000-2002. Fish were stocked near Verdel, Nebraska, on August 2, 2000; NTU = nephelometric turbidity units.

\begin{tabular}{|c|c|c|c|c|c|c|c|c|c|c|c|c|}
\hline \multirow[b]{2}{*}{ Habitat } & \multicolumn{6}{|c|}{ Spring } & \multicolumn{6}{|c|}{ Summer } \\
\hline & $\begin{array}{l}\text { Total } \\
\text { loca- } \\
\text { tions }\end{array}$ & $\begin{array}{c}\text { Temper- } \\
\text { ature } \\
\left({ }^{\circ} \mathrm{C}\right)\end{array}$ & $\begin{array}{l}\text { Depth } \\
\text { (m) }\end{array}$ & $\begin{array}{l}\% \text { Maxi- } \\
\text { mum } \\
\text { depth }\end{array}$ & $\begin{array}{c}\text { Turbidity } \\
\text { (NTU) }\end{array}$ & $\begin{array}{c}\text { Bottom } \\
\text { current } \\
\text { velocity } \\
(\mathrm{m} / \mathrm{s})\end{array}$ & $\begin{array}{l}\text { Total } \\
\text { loca- } \\
\text { tions }\end{array}$ & $\begin{array}{l}\text { Temper- } \\
\text { ature } \\
\left({ }^{\circ} \mathrm{C}\right)\end{array}$ & $\begin{array}{l}\text { Depth } \\
(\mathrm{m})\end{array}$ & $\begin{array}{l}\text { \% Maxi- } \\
\text { mum } \\
\text { depth }\end{array}$ & $\begin{array}{c}\text { Turbidity } \\
\text { (NTU) }\end{array}$ & $\begin{array}{c}\text { Bottom } \\
\text { current } \\
\text { velocity } \\
(\mathrm{m} / \mathrm{s})\end{array}$ \\
\hline Main channel & 49 & $7.5(1.0)$ & $4.6(0.7)$ & 85.3 (4.9) & $8(0.9)$ & $0.15(0.09)$ & 108 & $20.5(0.6)$ & $4.5(0.4)$ & $82.3(4.0)$ & $5(0.8)$ & $0.45(0.09)$ \\
\hline Island tip & 3 & $3.4(2.2)$ & $0.7(0.2)$ & $40.0(22.1)$ & 5 & No data & 0 & & & & & \\
\hline $\begin{array}{r}\text { Secondary } \\
\text { channel }\end{array}$ & 0 & & & & & & 6 & $24.0(1.2)$ & $3.0(1.1)$ & $88.4(10.7)$ & $11(4.1)$ & $0.51(0.10)$ \\
\hline Tributary & 0 & & & & & & 1 & 22.6 & 1.8 & 39.1 & No data & $0(0)$ \\
\hline Backwater & 0 & & & & & & 2 & $21.6(2.1)$ & $4.2(0.2)$ & $98.9(2.3)$ & $8(3.6)$ & No data \\
\hline Tailrace & 1 & 12.1 & 7.0 & 97.2 & No data & No data & 0 & & & & & \\
\hline
\end{tabular}

where relative depth ranged from $80 \%$ to $92 \%$. The habitat type with the second most observations was secondary channels $(4.4 \%)$, and these fish were found in areas where relative depth ranged from $84 \%$ to $88 \%$. Less than $2 \%$ of fish relocations occurred in each of the remaining habitat types (tailrace, island tips, backwaters, and tributaries). Bottom current velocities where juvenile pallid sturgeon were located ranged from 0.1 to $0.9 \mathrm{~m} / \mathrm{s}$; most fish were found in water greater than $3.0 \mathrm{~m}$ in depth. Turbidity in all years, seasons, and habitats was uniformly low (<12 NTU).

\section{Fish Movement}

After stocking in 2000, the juvenile pallid sturgeon generally remained near the stocking location or moved upstream (Figure 3). During 2001, the pallid sturgeon were distributed throughout the study area; by 2002 , the fish were generally using the entire riverine reach of the Missouri River (Figure 3). During the spring, juvenile pallid sturgeon generally were found more frequently in the middle and upper portions of the study reach, whereas summer locations were distributed across the entire study area (Figure 4). By fall, fish were located less frequently in zone 1 than the other three zones. The directionality of individual pallid sturgeon movements (upstream versus downstream) was not significantly influenced by year, but directionality of fish movement was significantly influenced by season; fish generally moved upstream in spring and downstream during summer (Table 4).

Clusters of juvenile pallid sturgeon (two or more fish within $750 \mathrm{~m}$ of each other) were observed on 15 dates. On seven of those dates, at least two study fish were found within $500 \mathrm{~m}$ or less of each other, and on three dates (once during 2001 and twice during 2002) at least two fish were located within $250 \mathrm{~m}$ of each other. The smallest calculated distance between two fish was $43 \mathrm{~m}$ during summer of 2001. Clusters were observed in all seasons: seven dates in spring, six in summer, one in fall, and one in winter.

The mean range of movement ( $\pm 2 \mathrm{SE}$ ) of the eight pallid sturgeon found multiple times every year during extensive tracking was $8.3 \pm 5.6 \mathrm{~km}$ in 2000 and expanded over threefold to $29.3 \pm 8.8 \mathrm{~km}$ in 2001 and to $28.9 \pm 15.0 \mathrm{~km}$ in 2002 (Figure 5a). This increased range of movement in 2001 and 2002 was significant (repeated-measures ANOVA: $F=6.09, \mathrm{df}=2, P=$ $0.01)$ and was not due to differences among individuals (repeated-measures ANOVA: $F=1.51, \mathrm{df}=7, P=$ $0.24)$. Although all fish appeared to have similar ranges among the years, our interpretations are limited because the range of movement may have been influenced by the greater sampling effort in 2001 and 2002. Seasonal ranges of juvenile pallid sturgeon were marginally significantly different (repeated-measures ANOVA: $F=2.71, \mathrm{df}=2, P=0.10)$, and ranges in fall were smaller than those in spring (Figure $5 b$ ).

Intensive tracking of individual juvenile pallid sturgeon revealed no significant differences in movement rates among years (Kruskal-Wallis: $\chi^{2}=2.00, \mathrm{df}$ $=2, P=0.37$ ), seasons (Kruskal-Wallis: $\chi^{2}=3.35$, df $=2, P=0.19$ ), or diel periods (repeated-measures ANOVA: $F=0.06$, df $=3, P=0.98$ ). Median annual movement rates ranged from 0.02 to $0.11 \mathrm{~km} / \mathrm{h}$. The maximum movement rate $(0.27 \mathrm{~km} / \mathrm{h})$ of an individual fish was observed during 2002. Median seasonal movement rates were $0.08 \mathrm{~km} / \mathrm{h}$ in fall, $0.07 \mathrm{~km} / \mathrm{h}$ in spring, and $0.03 \mathrm{~km} / \mathrm{h}$ during summer. Maximum movement rates were $0.26 \mathrm{~km} / \mathrm{h}$ in fall, $0.13 \mathrm{~km} / \mathrm{h}$ in spring, and $0.15 \mathrm{~km} / \mathrm{h}$ in summer. Median and maximum diel movement rates were 0.06 and 0.21 $\mathrm{km} / \mathrm{h}$ at dawn, 0.04 and $0.37 \mathrm{~km} / \mathrm{h}$ during daytime, 0.03 and $0.18 \mathrm{~km} / \mathrm{h}$ at dusk, and 0.05 and $0.21 \mathrm{~km} / \mathrm{h}$ at 
TABLE 3.--Extended.

\begin{tabular}{|c|c|c|c|c|c|c|c|c|c|c|c|c|}
\hline \multirow[b]{2}{*}{ Habitat } & \multicolumn{6}{|c|}{ Fall } & \multicolumn{6}{|c|}{ Winter } \\
\hline & $\begin{array}{l}\text { Total } \\
\text { loca- } \\
\text { tions }\end{array}$ & $\begin{array}{c}\text { Temper- } \\
\text { ature } \\
\left({ }^{\circ} \mathrm{C}\right)\end{array}$ & $\begin{array}{c}\text { Depth } \\
\text { (m) }\end{array}$ & $\begin{array}{c}\text { \% Maxi- } \\
\text { mum } \\
\text { depth }\end{array}$ & $\begin{array}{c}\text { Turbidity } \\
\text { (NTU) }\end{array}$ & $\begin{array}{c}\text { Bottom } \\
\text { current } \\
\text { velocity } \\
(\mathrm{m} / \mathrm{s})\end{array}$ & $\begin{array}{l}\text { Total } \\
\text { loca- } \\
\text { tions }\end{array}$ & $\begin{array}{c}\text { Temper- } \\
\text { ature } \\
\left({ }^{\circ} \mathrm{C}\right)\end{array}$ & $\begin{array}{l}\text { Depth } \\
\text { (m) }\end{array}$ & $\begin{array}{l}\text { \% Maxi- } \\
\text { mum } \\
\text { depth }\end{array}$ & $\begin{array}{c}\text { Turbidity } \\
\text { (NTU) }\end{array}$ & $\begin{array}{c}\text { Bottom } \\
\text { current } \\
\text { velocity } \\
(\mathrm{m} / \mathrm{s})\end{array}$ \\
\hline Main channel & 38 & $16.1(0.8)$ & $3.9(0.5)$ & $80.4(6.0)$ & $5(1.2)$ & $0.46(0.07)$ & 12 & $1.1(0.1)$ & $3.5(0.8)$ & $91.8(4.8)$ & No data & No data \\
\hline Island Tip & 1 & 11.7 & 0.9 & 17.0 & 5 & No data & 0 & & & & & \\
\hline $\begin{array}{r}\text { Secondary } \\
\text { channel }\end{array}$ & 4 & $13.7(4.3)$ & $3.6(0.5)$ & $83.9(13.4)$ & $8(1.4)$ & $0.39(0.13)$ & 0 & & & & & \\
\hline Tributary & 2 & $18.7(1.0)$ & $5.7(4.2)$ & $66.2(53.3)$ & 1 & 0.71 & 0 & & & & & \\
\hline $\begin{array}{l}\text { Backwater } \\
\text { Tailrace }\end{array}$ & 0 & & & & & & 0 & & & & & \\
\hline
\end{tabular}

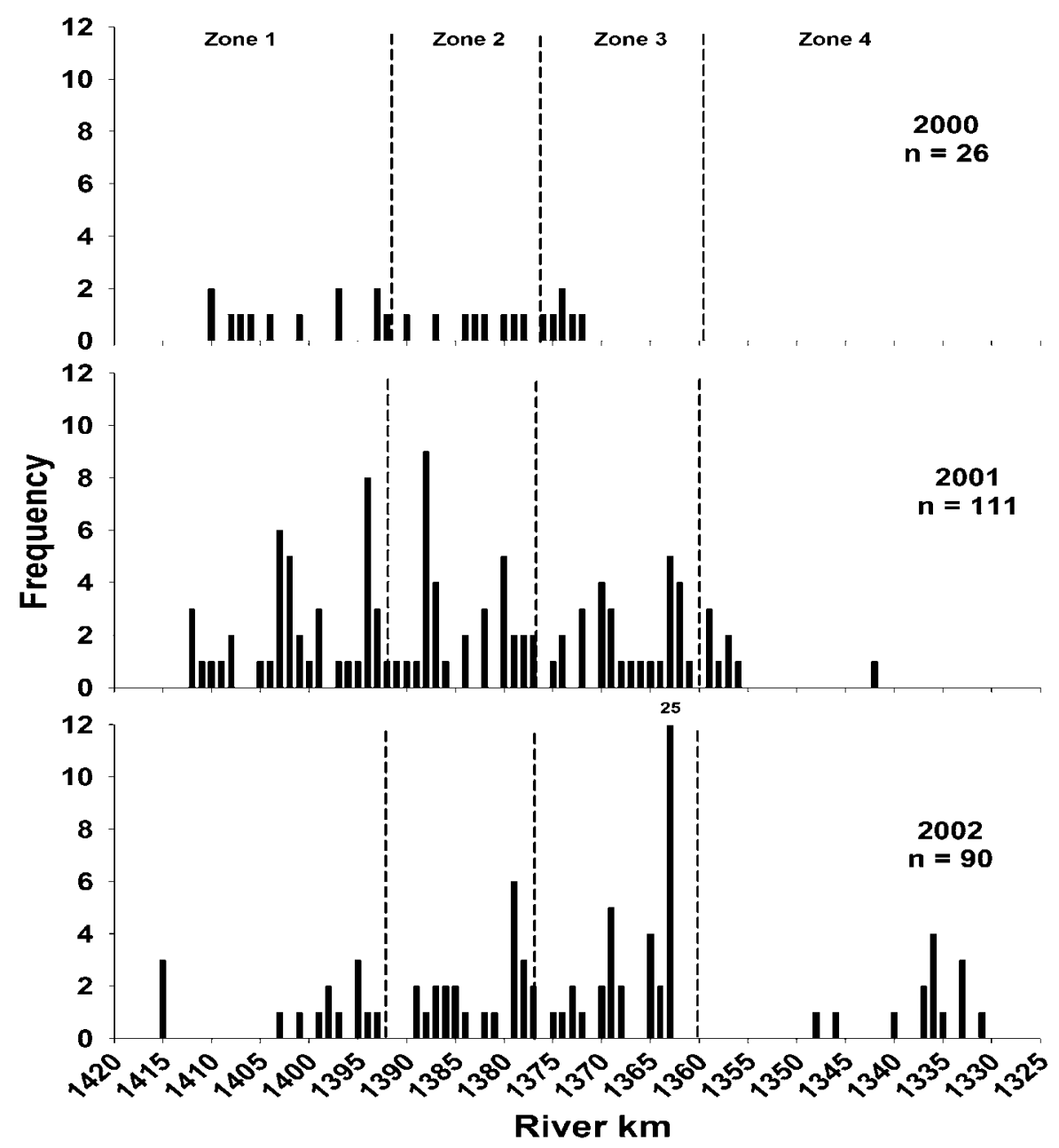

FIGURE 3.- Yearly distributions by zone (Figure 1) for sonically tagged, hatchery-reared juvenile pallid sturgeon relocated in the Missouri River downstream of Fort Randall Dam, South Dakota and Nebraska, during 2000-2002. The stocking location of Verdel, Nebraska, was near the boundary between zones 2 and $3 ; n$ is the number of sonic tag relocations made in the given year. 


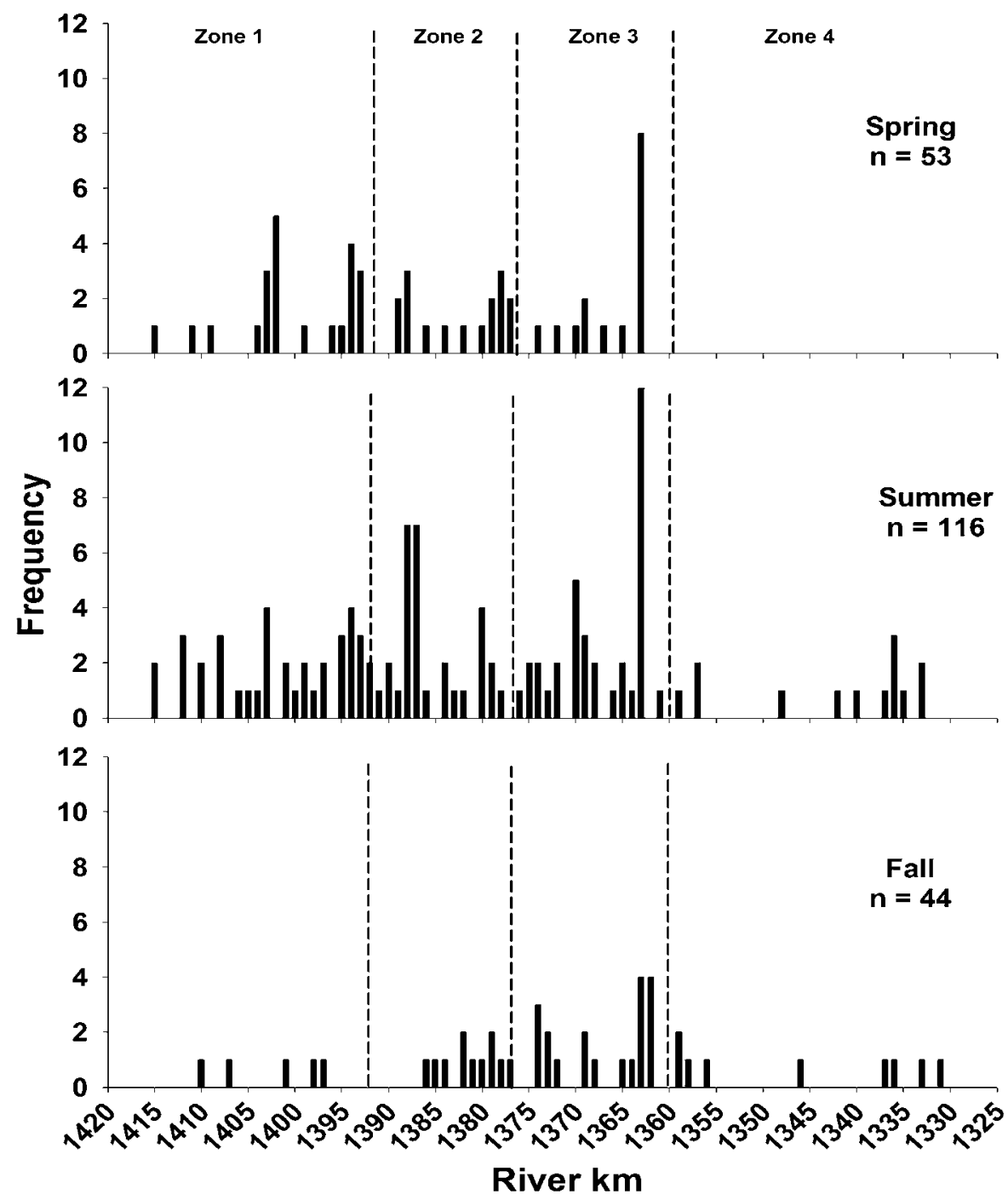

FIGURE 4.- - Seasonal distributions by zone (Figure 1) for sonically tagged, hatchery-reared juvenile pallid sturgeon relocated in the Missouri River downstream of Fort Randall Dam, South Dakota and Nebraska, during 2000-2002. The stocking location of Verdel, Nebraska, was near the boundary between zones 2 and 3; $n$ is the number of sonic tag relocations made in the given season.

night (Figure 6). Minimum movement rates for all the diel periods were $0.1 \mathrm{~km} / \mathrm{h}$ or less.

\section{Discussion}

Despite the fact that our transmitter weight : fish body weight ratio $(2.1-3.5 \%)$ exceeded the recommended maximum of $2 \%$ (Nielsen 1992), these ratios did not appear to affect the survival rate of pallid sturgeon. All fish had high relative condition factors $(>1)$, indicating good health (Table 1), but tag expulsion was high. Attempts to reinsert expelled transmitters were unsuccessful, probably because of the additive effect of stress to these fish, which may have contributed to the observed high mortality. Subsequently, study fish that showed signs of ruptured sutures or severe infection were euthanized. Water temperatures were at or near $20^{\circ} \mathrm{C}$ during the 2 -week holding period, which may have been more of a factor affecting survival than transmitter size. Shovelnose sturgeon S. platorynchus implanted with transmitters demonstrated greater healing success at $10^{\circ} \mathrm{C}$ than at water temperatures near $20^{\circ} \mathrm{C}$; the higher water temperatures may have contributed to bacterial infections (Swigle 2003). Conversely, too cold water 
TABLE 4.-Chi-square results comparing annual and seasonal directionality of juvenile hatchery-reared pallid sturgeon movements in the Missouri River below Fort Randall Dam.

\begin{tabular}{lrrrr}
\hline & \multicolumn{2}{c}{ Direction } & & \\
\cline { 2 - 3 } Variable & Upstream & Downstream & $\chi^{2}(\mathrm{df})$ & $P$ \\
\hline Year & & & & \\
2000 & 9 & 2 & $2.89(2)$ & 0.24 \\
2001 & 60 & 45 & & \\
2002 & 40 & 33 & & \\
Season & & & $10.45(2)$ & $<0.01$ \\
$\quad$ Spring & 22 & 11 & & \\
Summer & 33 & 60 & & \\
Fall & 12 & 10 & &
\end{tabular}

temperatures may limit healing. The incision wound on one adult pallid sturgeon, captured and tagged in the cold waters of the tailrace of Fort Peck Dam in Montana during July, failed to heal completely after 5 months (Tews 1994). Using radio tags that weighed less than $1.2 \%$ of body weight for larger $(1.2-2.5 \mathrm{~kg})$ and older (age 6) juvenile pallid sturgeon than were used in this study, Snook et al. (2002) also found 50\% of their fish shed tags after release in the Platte River, Nebraska, in April. Anesthesia during surgery may reduce stress levels and increase survival. Hurley (1998) anesthetized adult pallid sturgeon with $\mathrm{CO}_{2}$ (85 L/min for 3-6 $\mathrm{min}$ ) before surgery and subsequently relocated $75 \%$ of the fish within $100 \mathrm{~d}$ of release. Fish in our study and that of Snook et al. (2002) were not anesthetized while the tags were inserted. Further research of temperature effects and anesthesia use on healing rates could be beneficial to limit mortalities or transmitter losses. Another potential factor that could have influenced implantation success and, ultimately, postimplantation survival rates (Cook and Wagner 2004) was skill disparity among individuals performing the surgeries; that is, multiple biologists with varying experience levels implanted transmitters.

Although the pallid sturgeon we tagged experienced high initial mortality (56\%), use of larger transmitters with longer battery life $(1,000 \mathrm{~d})$ provided information on movement in the second and third years after stocking. Most telemetry studies with pallid sturgeon have used short-duration transmitters (90-400 d; Erickson 1992; Tews et al. 1994; Snook et al. 2002; Swigle 2003; Gerrity 2005). These short-term studies provide initial insights into survival, movement, and habitat use but should be interpreted cautiously because hatchery-reared fish may not have acclimated to a natural riverine environment or to the presence of the internal transmitter. The risk of mortality from using
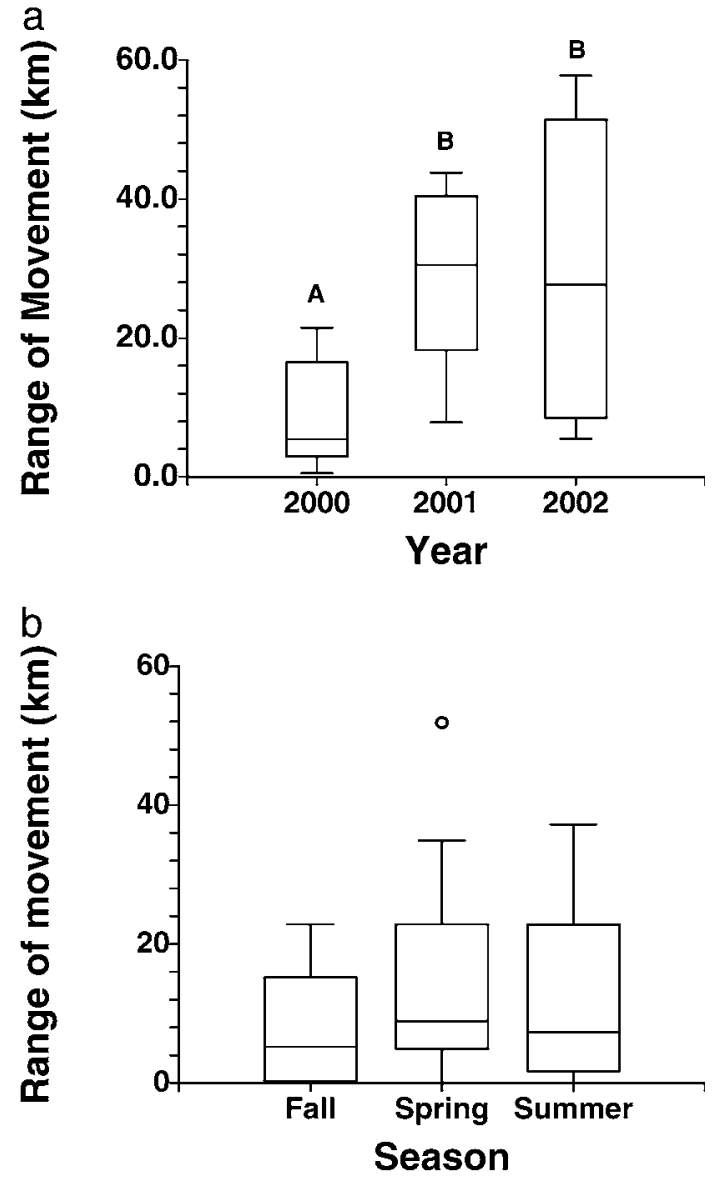

FIGURE 5.-Box plots (horizontal line $=$ median, box $=$ interquartile range, whiskers are defined in Methods) of the (A) annual and (B) seasonal ranges of movement by sonically tagged, hatchery-reared juvenile pallid sturgeon relocated in the Missouri River downstream of Fort Randall Dam, South Dakota and Nebraska, during 2000-2002. For panel (A), differing letters denote significant differences between years (repeated-measures ANOVA; Tukey-Kramer $90 \%$ familylevel confidence intervals; $\alpha=0.10$ ).

large transmitters that have a battery life greater than 1 year must be weighed against the short-term behavior immediately after stocking.

\section{Habitat}

Throughout this study, hatchery-reared juvenile pallid sturgeon were primarily located in the main channel, and few fish were found in secondary channels and backwaters (Table 3). In 56\% of extensive surveys, we found at least two juvenile pallid sturgeon within $750 \mathrm{~m}$ of each other, which indicates that these hatchery fish were not uniformly 
A)

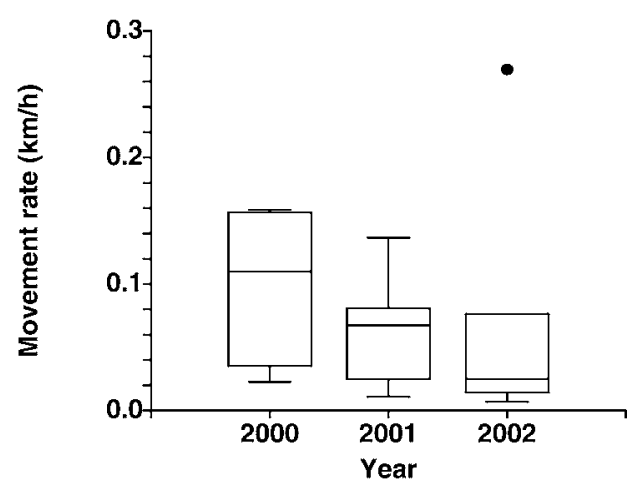

B)

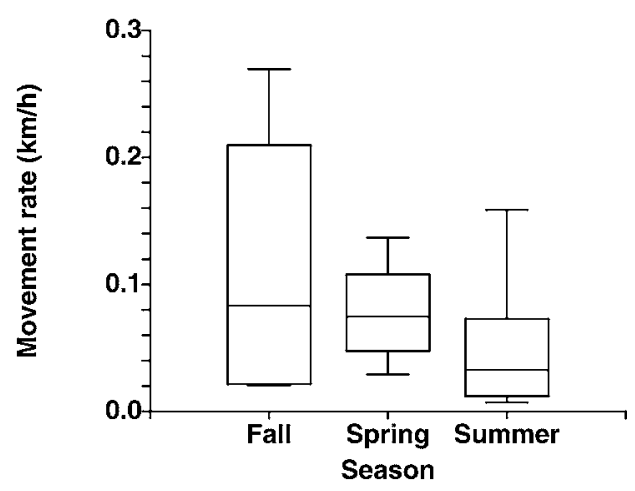

C)

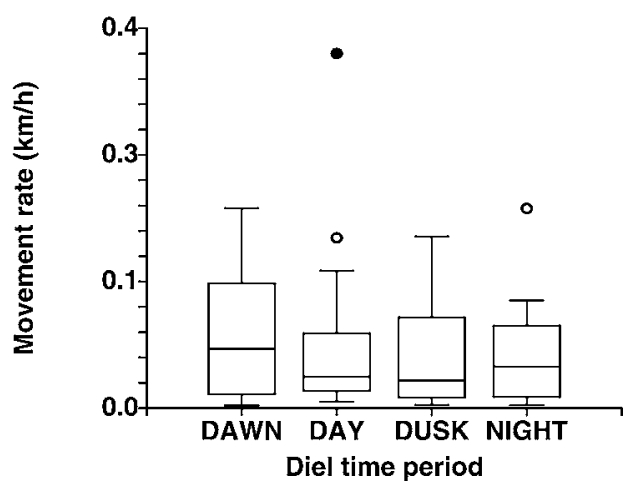

Figure 6.-Box plots (horizontal line $=$ median, box $=$ interquartile range, whiskers are defined in Methods) of median (A) annual, (B) seasonal, and (C) diel movement rates of sonically tagged, hatchery-reared juvenile pallid sturgeon relocated in the Missouri River downstream of Fort Randall Dam, South Dakota and Nebraska, during 2000-2002. Movement rates were calculated from intensive surveys (i.e., hourly relocations of a single fish). Movement rates did not differ significantly among years, seasons, or diel periods. distributed. There were only six locations within this 85-rkm reach of the Missouri River where we observed clusters of hatchery-reared juvenile pallid sturgeon. At three of these locations, we observed clusters on two or more occasions. Juveniles were commonly found in all seasons (Figure 4) at $\mathrm{rkm}$ 1,363, an area with the greatest measured water depths $(\geq 10 \mathrm{~m})$ in the study reach. Probably some unknown combination of abiotic and biotic conditions existed at these six locations. In August and October 2002, the U.S. Geological Survey collected bathymetric data and used side-scan sonar to collect images of habitat features in areas where 12 of our sonically tagged juveniles were relocated; they also examined unoccupied areas to assess habitat availability and selection (Elliott et al. 2004). They found that juvenile pallid sturgeon selected large sand dunes in the main channel more than any other habitat available in the Missouri River below Fort Randall Dam. In the Missouri River above Fort Peck Reservoir, Montana, hatchery-reared pallid sturgeon used main-channel habitats more so than secondary channels (Gerrity 2005). In the middle Mississippi River, Hurley et al. (2004) found that wild adult pallid sturgeon used the main channel (39\% of all relocations), despite negative selection for this habitat, but fish positively selected main-channel border habitats $(26 \%)$. In the Platte River, Snook et al. (2002) relocated hatchery-reared juvenile pallid sturgeon adjacent to the main channel (characterized by sharp changes in depth) but never found them directly in the main channel. Bramblett and White (2001) found wild adult pallid sturgeon in the Yellowstone River, Montana, and Missouri River, North Dakota, selected sinuous and dynamic river reaches with many islands and secondary channels. Middle Mississippi River adult pallid sturgeon selected more diverse habitats downstream of island tips and wing dams, despite the low abundance of these habitats (Hurley et al. 2004). However, Gerrity (2005) found that juvenile pallid sturgeon (ages 6-7) did not select areas with islands or alluvial sand bars in the Missouri River above Fort Peck Reservoir. Although our hatchery-reared juvenile pallid sturgeon were relocated in the main channel, these areas were generally associated with current breaks from hard points, submerged sand bars, or large snags. Juvenile pallid sturgeon may use these current breaks as refuge from water velocities and to effectively feed.

Hatchery-reared juvenile pallid sturgeon released in the Missouri River downstream of Fort Randall Dam appeared to occupy habitats similar to pallid sturgeon studied elsewhere. The mean bottom current velocity where all study fish were relocated was less than 0.75 $\mathrm{m} / \mathrm{s}$ (Table 3). Gerrity (2005) observed average bottom current velocities between 0.45 and $0.50 \mathrm{~m} / \mathrm{s}$ in areas 
where hatchery-reared juvenile pallid sturgeon were relocated in the upper Missouri River. In the lower Platte River, Snook et al. (2002) found that $91 \%$ of pallid sturgeon relocations had bottom current velocities less than $0.70 \mathrm{~m} / \mathrm{s}$. Others found that most wild pallid sturgeon adults in the Yellowstone and Missouri rivers (Bramblett and White 2001) and below Oahe Dam, South Dakota (Erickson 1992), used bottom current velocities ranging from 0 to $1 \mathrm{~m} / \mathrm{s}$, and some fish were found in velocities up to $1.6 \mathrm{~m} / \mathrm{s}$ (Bramblett and White 2001). Based on detailed flow measurements from an acoustic Doppler current profiler, Elliot et al. (2004) found that 12 of our sonically tagged juvenile pallid sturgeon used moderate to high bottom current velocities $(0.69-1.01 \mathrm{~m} / \mathrm{s})$ in the same proportion to availability in the Fort Randall reach of the Missouri River.

Pallid sturgeon are considered to inhabit deep, turbid waters in the main channel of large rivers (Kallemeyn 1983). However, both hatchery-reared juvenile and wild adult pallid sturgeon have been located in shallow waters $(<1 \mathrm{~m}$; Bramblett and White 2001; Snook et al. 2002). Hatchery-reared pallid sturgeon in the upper Missouri River above Fort Peck Reservoir generally did not occupy the deepest water available but rather were found in areas that were $17-27 \%$ shallower than the maximum cross-sectional depth (Gerrity 2005). Wild adult pallid sturgeon occupied somewhat smaller relative depths in the Missouri River below Fort Peck Dam; this result may be due to low water clarity (Bramblett and White 2001). In the lower Platte River, Snook et al. (2002) relocated their study fish in depths from 0.2 to $1.7 \mathrm{~m}$ (mean $=0.8 \mathrm{~m})$. All hatchery-reared juveniles in our study were predominately found in the main channel at relative depths exceeding $80 \%$ (Table 3). Water clarity in the Missouri River below Fort Randall Dam was uniformly high $(<12$ NTU) throughout our study (Table 3), which may account for the greater relative depths occupied by juvenile pallid sturgeon than by wild adults in the Missouri and Yellowstone rivers (Bramblett and White 2001). Adult pallid sturgeon in Lake Sharpe, South Dakota, were most commonly located in waters with bottom turbidities exceeding 80 NTU (Erickson 1992). Given the similarity of behavior demonstrated between the hatchery-reared pallid sturgeon in our study and both wild adults and hatchery-reared pallid sturgeon studied elsewhere, we conclude this reach of the Missouri River appears suitable for continued supplementation efforts to promote species recovery.

\section{Movement}

Past telemetry studies (Hurley 1998; Bramblett and White 2001; Snook et al. 2002) have described the high mobility of pallid sturgeon. Range of movement for hatchery-reared juvenile pallid sturgeon above Fort Peck Reservoir was between 1 and 74 km (Gerrity 2005). The extent of annual movement observed for adult pallid sturgeon in the Missouri and Yellowstone rivers in Montana was $20-80 \mathrm{~km}$, but some fish moved distances greater than $200 \mathrm{~km}$ during spring and summer (Bramblett and White 2001). The mean extent of movements by adult pallid sturgeon in the Mississippi River was $34 \mathrm{~km}$, but that was considered a minimum estimate (Hurley 1998). Juvenile pallid sturgeon stocked in the Platte River moved 40-60 km downstream within 3-4 months (Snook et al. 2002). We observed that most individuals ranged at least 8 $\mathrm{km}$. However, upstream movements were restricted by Fort Randall Dam, and this minimum range may not be applicable to larger river reaches. Distribution of the fish changed over the 3 years of our study, suggesting that the transition from the hatchery to the river was not immediate. During the second and third years after release, hatchery-reared juvenile pallid sturgeon used almost the entire riverine reach of the Missouri River below Fort Randall Dam. A short, 1-year study would have incorrectly concluded that most fish moved upstream after stocking, lessening the perceived importance and use of habitats downstream. This poststocking dispersal pattern suggests that the single stocking location near Verdel, Nebraska, is sufficient to support pallid sturgeon recovery efforts within this reach of the Missouri River.

Pallid sturgeon can have substantial daily and seasonal movements. Wild adults in the Missouri River moved up to $21 \mathrm{~km} / \mathrm{d}$ and were most active in spring (Erickson 1992; Bramblett and White 2001). Wild adults below the confluences of the Missouri and Yellowstone rivers had directed upstream movements into the Yellowstone River during spring (Bramblett and White 2001). Four juvenile pallid sturgeon in the Platte River also had the same general movement pattern, but some fish changed directions midseason (Snook et al. 2002). However, middle Mississippi River wild adults moved both upstream and downstream during spring (Hurley 1998). Based on intensive tracking data, we found similar movements in hatchery-reared juvenile pallid sturgeon stocked below Fort Randall Dam. After stocking, movement rates of our study fish ranged from 0.3 to $9.0 \mathrm{~km} / \mathrm{d}$. Seasonally, these fish moved 2.5 times more in the spring and fall than in summer (Figure 6), and movement rates were generally directed upstream during spring and downstream during summer (Table 4).

Patterns in diel activity levels for pallid sturgeon have been observed. Bramblett and White (2001) found a greater proportion of wild adult pallid sturgeon 
moved during the day (56\%) than at night $(37 \%)$ and hypothesized that pallid sturgeon would become more nocturnal in low-turbidity habitats. However, mean adult pallid sturgeon 2-h movement rates in the middle Mississippi River were significantly greater during the day than at night (Hurley 1998). In the turbid Platte River, pallid sturgeon intensively tracked for $12 \mathrm{~h}$ did not move during the day or night (Snook et al. 2002). We also did not find evidence to support the increase of nocturnal activity with decreased turbidity hypothesis. Increased nocturnal activity by hatchery-reared juvenile pallid sturgeon in the clear waters below Fort Randall Dam was not evident in our study.

Overall, we found juvenile hatchery-reared pallid sturgeon moved throughout the Missouri River below Fort Randall Dam, behaved similarly to both wild and hatchery-reared pallid sturgeon studied elsewhere, and appeared to acclimate to and use the entire riverine reach identified as RPMA 3 (Dryer and Sandvol 1993). Survival of sonically tagged juvenile pallid sturgeon stocked into RPMA 3 appeared to be good $(68 \%$ survived for 2.5 years). Observed minimum survival rates from our study are similar to survival rates reported for hatchery-reared juvenile white sturgeon Acipenser transmontanus stocked in the Kootenai River (Ireland et al. 2002). These observations suggest that RPMA 3 has the potential to maintain stocked pallid sturgeon and should be utilized in recovery efforts. However, whether conditions are present to enable a self-sustaining population, the ultimate determinate of recovery success, remains unknown.

\section{Acknowledgments}

Field assistance was provided by Dawn Rousch, Robert (Hank) Johnson, and Paul Dummond. Funding was provided by the U.S. Fish and Wildlife Service (USFWS), Western Area Power Association, and the U.S. Army Corps of Engineers. A second receiver was provided by Gerald Mestl (Nebraska Game and Parks Commission, Lincoln). Herb Bollig and his staff at the USFWS Gavins Point Dam NFH provided the study fish and assisted with the surgery. Bryan Spindler provided GIS-related distance measurements. This manuscript was improved by constructive comments provided by Keith Hurley and Dane Shuman. The findings and conclusions in this article are those of the authors and do not necessarily represent the views of the U.S. Fish and Wildlife Service.

\section{References}

Bramblett, R. G., and R. G. White. 2001. Habitat use and movement of pallid and shovelnose sturgeon in the Yellowstone and Missouri rivers in Montana and North
Dakota. Transactions of the American Fisheries Society 130:1006-1025.

Cook, S. J., and G. N. Wagner. 2004. Training, experience, and opinions of researchers who use surgical technique to implant telemetry devices into fish. Fisheries 29(12):10 17.

Dryer, M. P., and A. J. Sandvol. 1993. Pallid sturgeon, Scaphirhynchus albus, recovery plan. U.S. Fish and Wildlife Service, Washington, D.C.

Elliott, C. M., R. B. Jacobson, and A. J. DeLonay. 2004. Physical aquatic habitat assessment, Fort Randall segment of the Missouri River, Nebraska and South Dakota. U.S. Geological Survey, Open-File Report 2004-1060, Columbia Environmental Research Center, Columbia, Missouri.

Erickson, J. D. 1992. Habitat selection and movement of pallid sturgeon in Lake Sharpe, South Dakota. Master's thesis. South Dakota State University, Brookings.

ESRI (Environmental Systems Research Institute). 1999. ArcView 3.2. ESRI, Redlands, California.

Fogle, N. E. 1961. Report of the fisheries investigations during the third year of impoundment of Oahe Reservoir, South Dakota, 1960. South Dakota Department of Game, Fish, and Parks, DJ Project F-1-R-10 Report, Pierre.

Forbes, S. A., and R. E. Richardson. 1905. On a new shovelnose sturgeon from the Mississippi River. Bulletin of the Illinois State Laboratory of Natural History 7:39-44.

Gerrity, P. C. 2005. Habitat use, diet, and growth of hatchery reared juvenile pallid sturgeon and indigenous shovelnose sturgeon in the Missouri River above Fort Peck Reservoir. Master's thesis. Montana State University, Bozeman.

Hintze, J. L. 2005. User guide. Introduction data graphics, NCSS statistical system. NCSS, Kaysville, Utah.

Hurley, K. L. 1998. Habitat use, selection, and movements of middle Mississippi River pallid sturgeon and validity of pallid sturgeon age estimates from pectoral rays. Master's thesis. Southern Illinois University, Carbondale.

Hurley, K. L., R. J. Sheehan, R. C. Heidinger, P. S. Wills, and B. Clevenstine. 2004. Habitat use by middle Mississippi River pallid sturgeon. Transactions of the American Fisheries Society 133:1033-1041.

Ireland, S. C., R. C. P. Beamesderfer, V. L. Paragamian, V. D. Wakkinen, and J. T. Siple. 2002. Success of hatcheryreared juvenile white sturgeon (Acipenser transmontanus) following release in the Kootenai River, Idaho, USA. Journal of Applied Ichthyology 18:642-650.

Kallemeyn, L. W. 1983. Status of the pallid sturgeon, Scaphirhynchus albus. Fisheries 8(1):3-9.

Keenlyne, K. D., and P. D. Evenson. 1993. Standard and relative weight for the pallid sturgeon, Scaphirhynchus albus. Proceedings of the South Dakota Academy of Sciences 72:4149.

Keenlyne, K. D., and L. G. Jenkins. 1993. Age at sexual maturity of the pallid sturgeon. Transactions of the American Fisheries Society 122:393-396.

Nielsen, L. A. 1992. Methods of marking fish and shellfish. American Fisheries Society, Special Publication 23, Bethesda, Maryland.

Pegg, M. A., C. L. Pierce, and A. Roy. 2003. Hydrological alteration along the Missouri River basin: a time series approach. Aquatic Sciences 65:63-72. 
Snook, V. A., E. J. Peters, and L. J. Young. 2002. Movements and habitat use by hatchery-reared pallid sturgeon in the lower Platte River, Nebraska. Pages 161-175 in W. VanWinkle, P. J. Anders, D. H. Secor, and D. A. Dixon, editors. Biology, management and protection of North American sturgeon. American Fisheries Society, Symposium 28, Bethesda, Maryland.

Sprent, P., and N. C. Smeeton. 2001. Applied nonparametric statistical methods, 3rd edition. Chapman and Hall/CRC, Boca Raton, Florida.

Swigle, B. D. 2003. Movements and habitat use by shovelnose and pallid sturgeon in the lower Platte River, Nebraska. Master's thesis. University of Nebraska, Lincoln.

Tews, A. 1994. Pallid sturgeon and shovelnose sturgeon in the Missouri River from Fort Peck Dam to Lake Sakakawea and in the Yellowstone from intake to its mouth. Montana Department of Fish, Wildlife and Parks, Final Report to the Army Corps of Engineers, Omaha, Nebraska.

Venables, W. N., D. M. Smith, and the R Development Core Team. 2006. An introduction to $\mathrm{R}$, notes on $\mathrm{R}$ : a programming environment for data analysis and graphics version 2.4.0 (2006-10-3). R Foundation for Statistical Computing, Vienna, Austria. Available: www.r-project. org. (October 2006).

Winter, J. 1996. Advances in underwater biotelemetry. Pages 555-590 in B. R. Murphy and D. W. Willis, editors. Fisheries techniques, 2nd edition. American Fisheries Society, Bethesda, Maryland. 